\title{
The Arab Spring: Do We Need a New Theory?
}

\author{
Hisham H. Abdelbaki \\ Department of Economics, Mansoura University, Mansoura, Egypt \\ Email: habdelbaki@hotmail.com
}

Received January 13, 2013; revised February 14, 2013; accepted March 9, 2013

\begin{abstract}
The waves of the Arab Spring in Tunisia, Egypt, Libya, Yemen and Syria, and any other country that may follow, is considered a unique phenomenon worth studying in view of the pre and post revolution events and effects on all sectors of the national economy, as well as their interlocking effects on the global economy. The current research aims at studying the concepts of the Arab Spring, its causes and its most important consequences, as well as the ability of the current economic theory to interpret such events. The most important results of the research lies in the need for a new theory to explain the Arab Spring revolutions, the new theory should based on showing how important was the technological revolution in the field of communications, the use of violence against the rebels, and legitimate demands of rebels in continuation and success of the revolutions of the Arab Spring.
\end{abstract}

Keywords: Arab Spring; Political Unrest; New Theory; Egypt

\section{Introduction}

The revolution in Egypt—as one of the Arab Spring countries-began by a series of popular movements on Tuesday, January 25, 2011, to protest against the economic, social and political conditions, those protests continued and gained momentum and eventually led to the resignation of President Mubarak from power on February 11, 2011, when the Vice President Mr. Omar Suleiman announced in a brief statement at 6 PM of Friday, February 11, 2011, that president Mubarak decided to step down from office and that the Supreme Council of the Armed Forces will assume the country's administration. The period from February 2011 to July 2012 represented a period of historic transformation in the Egyptian economy. The relinquish of power by the former Egyptian President on February 11, 2011 ended thirty years of authoritarian rule and opened the doors to a new era of desired change, freedom and democracy. However, the revolution that led to the end of Mubarak's era greatly influenced the development and growth in the Egyptian economy, where the growth rate in real GDP of $5.1 \%$ in 2010 was decreased to $1.8 \%$ in 2011 , it also led a negative growth estimated at $4.2 \%$ during the first quarter of 2011. The sectors that support the economy in the provision of hard currency fell sharply in revenue. Foreign cash inflow has decreased from 6.4 billion dollars in 2010 to 482.7 million dollars in 2011, and for the tourism sector-responsible for hiring nearly $10 \%$ of the population-has suffered a decline in foreign tourism by $30 \%$, according to central bank data. Also the Suez Canal revenues and Egyptian exports also fell down due to decreased foreign demand [1]. The author sees that studying the Arab Spring from all its dimensions can improve understanding of the key dynamics of political conflicts and it can also lead to a more systematic understanding of how these dynamics affect conflict resolution and post-conflict peace building.

The research aims at studying the concepts associated with the Arab Spring, its economic reasons, as well as its consequences, and then demonstrate the possibility of interpreting the Arab Spring revolutions in the light of the current economic framework of the prevailing economic literature, or that there should be a new theory that commensurate with the nature of these revolutions. We will adopt Egypt as the case study as the state in which the Arab Spring crystallized and proved fruitful.

\section{Analytical Framework}

Many studies dealt with economic causes of civil, regional and international wars and conflicts and presented their economic effects at various levels, but the Arab Spring revolutions or popular revolutions that took place in a number of Arab states led by Tunisia, Egypt, Libya and Yemen have special features, causes and consequences that differ much from the nature of civil wars, regional wars and wars between nations as well as armed and unarmed conflicts. Although this adds difficulty to the research and study process, but at the same time, gives special importance to the current research for the unique facts included which sometimes agree and some- 
times disagree with many points and contents of economic literature.

\subsection{Economic Concept of Political Unrest}

In nature, humans tend to live in peace which requires the provision of security. In other words, they need to feel secure for themselves, their families and their property. The desire of the human being to work and be productive declines in tense environment that lacks safety and security and also if he feels injustice and inequality [2], therefore, stable governments have increased interest in providing security and safety for their citizens at home and protect them from dangers when they are abroad. For that governments set aside part of their revenues to spend in this regard. There is no doubt that increasing tension in one country requires more spending, which requires increased taxation to provide the necessary funding for this purpose [3,4]. Tension or political unrest lead to the conversion of part of the state's resources allocated to produce civilian goods and services to produce materials and equipment used to face these disturbances, thus we can-economically-define revolutions as exploiting part of the state's resources in non-civilian production, or the transfer of part of the resources exploited for civil production of goods and services to the people to be exploited in the production of weapons, equipment, plans and strategies to resolve or stop the spread of the unrest. All this will be reflected in the form of low living standard, increased rates of inflation, and that may be accompanied by an increase in unemployment rates also if the state imports the weapons and equipment used to suppress the demonstrations and try to prevent the outbreak of revolutions. As for the Arab Spring revolutions, they can be defined as popular movements swept across the country to demand comprehensive change and were helped by the irresponsible behaviors and actions of the regime to gain legitimacy and momentum which led to higher demands until the regime was toppled.

\subsection{Economic Explanation of the Political Unrest}

Literature studied the determinants of civilian conflict and reasons of its onset. The main two determinants are motivation and feasibility. Motivation or incentives, it can be explained by distinguished between two possible incentives: negative - a grievance against the existing state of affairs and positive-a desire to get rich, which sometimes called greed [5]. These incentives - togethercalled "justice-seeking" in literature. Game theory is used to study this factor and its implication. The rebels are put on one side and government is put on the other side. The second factor is feasibility where the rebel group is viewed as an unusual type of business which can only prosper in special conditions [6]. This factor is called "looting-seeking" in literature. The civilian conflict often occurs as a result of actors' desire for private gain where the presence of a "lootable" resource base creates the incentive for looting-seeking rebellions. The main two factors affect on feasibility of rebellion are the number and opportunity costs of potential rebels and government's military strength. The first factor affects positively and the second effects negatively on the realization of rebellion. Justice-seeking rebellions may be caused by grievance and may aim at achieving justice. The onset of "justice-seeking" rebellion conditions are determined by the interaction between demand for and supply of justice. Demand for justice are determined by three factors; first the presence of a large number of unemployed and uneducated young man or social fractionalization. Second, political repression and third, economic dysfunction i.e. slow economic growth; high inflation; high income inequality and all other inequality aspects like inequality in education, health and power $[7,8]$. On the other side, supply of justice is determined by the cost of achieving justice. The achieving of justice cost is determined, in turn, by the opportunity cost of rebel labor and its constrained by the collective action problems associated with providing justice $[9,10]$. Identity can be added as a third determinant of civil conflict which is essential for group formation. Rebels will not act together unless they see themselves as being in the same boat [5]. In modeling the mentioned three factors, [11] labels them frustration, opportunity, and identity where [12,13] used concepts of greed and grievance. [14] stated that going to war require opportunity and willingness discarding identity from their model. Opportunity is possibilities that are alternatives where willingness is choosing of option(s) from possible alternative. No doubt that the costs and benefits are differ from one conflict to another according to its reasons, duration, results, and many other factors. The three factors affect the length of conflict where rebels need motivation to keep on fighting, and they need resource(s) to finance their fighting. Duration of the conflict is an important issue to study and expect. If rebels have perfect foresight, so the expected duration of the conflict coincides with the actual duration. But if they have rational expectation but not perfect foresight, then the observed duration of the conflict is a biased prediction of the expected duration [15].

The economic theory of political unrest argues that the motivation of unrest is not important. Instead, the capability to finance the unrest is the important factor for determining whether or not the country will experience political unrest [16]. The economic theory of political unrest assumes that perceived grievances and the lust for power are nearly equal in societies. The important issue is the feasibility of predation which determines the risk 
of conflict. Collier states that "it is not really matter whether rebels are motivated by greed, by a lust for power, or by grievance, as long as what causes conflict is the feasibility of predation".

\subsection{Economic Factors of the Political Unrest Risk}

Studies on the causes of various types of political unrest decide that certain conditions increase the likelihood of occurrence of these disturbances, those conditions are: First, the existence of a close relationship between poverty and political unrest [17-19] studies showed that a country with GDP per capita of $\$ 250$ annually is prone to political unrest by $15 \%$, this drops to half with higher GDP per capita of $\$ 600$ annually, also goes down again to about 4\% with higher GDP per capita of \$1250 annually, and goes to less than $1 \%$ in countries with an average income per individual higher than $\$ 5000$ per year. Second, the level of education is related to the possibility of political strikes through the opportunity cost to join the rebel group, an uneducated person would not lose much by joining rebel groups regardless of the accompanying risk or, the opportunity cost to join these groups is low or non-existent [16], especially with the correlation between the level of education and the chance of getting employment in poor countries [18]. Countries where $54 \%$ of young males are in secondary education may be subjected to political unrest, however, when this percentage is increased to $55 \%$, the chance of being subjected to political unrest drops from $14 \%$ to $10 \%$. Third, political unrest appears more in countries with high population growth rate. Each increase of $1 \%$ in the rate of population growth increases the risk of political unrest by $2.5 \%$. Fourth, also the risk of political unrest increases in countries with low level of income, every $1 \%$ decrease in the rate of growth of per capita income increases the risk of political unrest by $1 \%$ as well. Fifth, the ethnic and religious component of the population is also a factor that determinants political unrest, the existence of a dominant constituent of $45 \%$ - $90 \%$ of the population would be enough to double the risk of political unrest. Finally, technology can have an important role in the beginnings of revolutions, it also affect which path would such revolutions take and consequently, the extent of their success, through using the so called "The Contest Success Function (CSF)", which determines the resources devoted to conflict outcomes in the forms of losses and gains of the two sides of the conflict $[20,21]$.

\subsection{Tracks of Political Unrest}

In general, the starting spark of popular moves is the degrading conditions in the country. As a result of the poor economic and social conditions in the national economy, individuals feel dissatisfied with the level and quality of life, from here the idea of change occurs, changing their reality to what they feel better from their point of view. This requires starting to do something, this action may be legal or permitted, or illegal and unauthorized, and the first type may indicate demonstrations or formation of a lobby, while the second type may indicate to carry out bombing or hijacking acts. The reason for resorting to the second type is often because peaceful demonstrations are not allowed, or allowed initially then planned or unplanned things might happen from one or both parties, and the protestors may be dealt with violently, which could turn the demonstrations into a more complex aspect and raises the demands roof of the demonstrators themselves. If the demonstrations turned into wide bombing or hijacking acts, that lead to the depletion of the country's resources and the prevalence of insecurity and instability and that often do not bring the desired change, and the losses outweigh the gains - if any-and with the continuation of violence, the demonstration could turn into a revolution (see Figure 1).

\subsection{Interpretation of the Length of the Political Unrest}

Political unrest duration vary from one case to another for many reasons, these may not be confined to specific reasons, but we would rather decide that the length of the period of political unrest depends on the following important factors.

\subsubsection{Benefit of Some from Instability and Security Chaos Associated with Political Unrest}

Although political unrest adversely affect the national economy in general, but there are certain categories that make gains from these disturbances, so they do not tend to preserve peace and national security, but rather seek to work on insecurity and chaos, encouraging lawlessness and tampering with internal security and stability to achieve further gains [16,19].

\subsubsection{Stability and Peace Is a Public Good That Has the Characteristics of Public Goods}

Public goods are characterized by non-exclude and non-rival in use. The non-exclude property indicates the inability to prevent some of benefit from the goods when they are available. Once a good is available, everyone will be able to benefit equally from that good, the availability of internal security and stability means that all citizens, even those who do not contribute to them nor want to provide them, should enjoy them. The non-rival in use property indicates that availability of a certain good should not be affected if being used by others, the use of a good by some does not reduce the chance of 


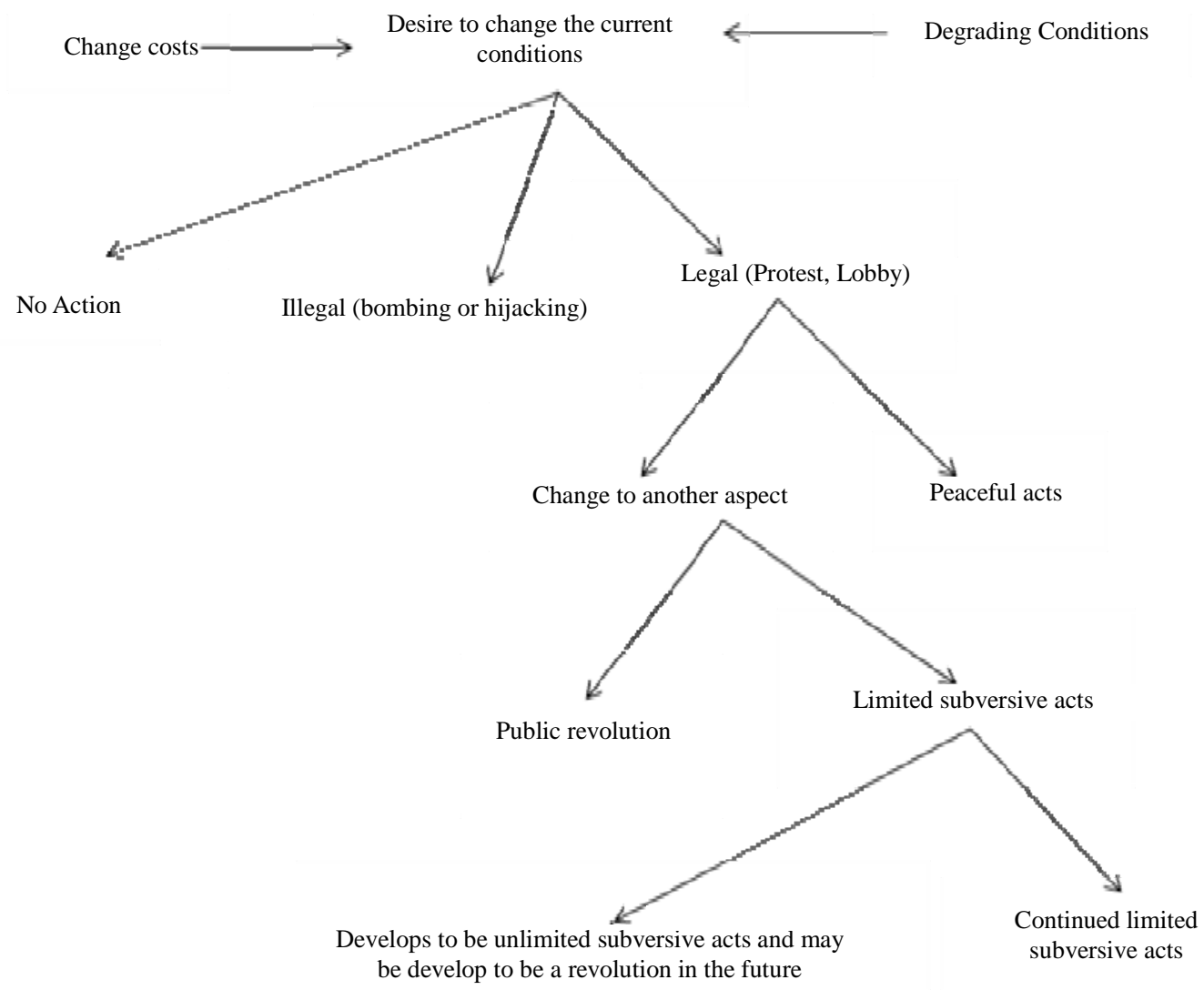

Figure 1. Political unrest paths. Source: designed by the author.

others to use the same good nor it does reduce their share of that good, thus, the use of security by some does not reduce the quality or quantity of security available for others. These two properties may result in less desire of some individuals to participate in providing security and stability, and would rather wait until they are available by efforts and contributions of others then use and benefit from them which is refereed to-economically-as the free riding problem. As a result, the desire of individuals and citizens to bear the burden of providing security and stability is much reduced and then, authorities must intervene and bear all the burden of providing security and stability prolonging the period of political unrest.

\subsubsection{The Marginal Cost of Achieving Security and Stability Exceed Their Marginal Utility}

Comparing the private marginal benefit and the private marginal cost to provide internal security and stability, we find that the costs exceed the benefits due to the non-inclusion of social benefit for security and stability. In the economic logic of security providers, this good is not economically feasible, and then the decision-makers may feel reluctant to provide this good due to its high cost and the lack of understanding of its total benefit. Because of this, the internal security and stability is delayed due to the economic short sight of decision-makers.

\subsubsection{Lack of or Delayed Response to the Demands of the Demonstrators}

The lack of or delayed response of authorities to the demands of the demonstrators may cause political unrest to turn from one form to another. In Egypt for example, the late response by the regime to demonstrators' demands led to the increase in their demands each time, until they reached their peak by demanding the over-throw of the regime, a demand the rebels did not give it up after that.

\subsection{Impact of Political Unrest on the National Economy}

First of all, we recognize that the results of political unrest vary from one case to another depending on many factors, including the evolution extent of these disturbances, spread of such disturbances to cover more areas, how they were dealt with by the authorities and the duration and place of these disturbances. Results increase whenever political unrest occurs in large and densely populated cities, and the biggest impact of the demonstrations would be in the country's capital rather than in a small town.

Political unrest leads to decline in GDP, which negatively affects government revenues, and then affects government spending in general and spending on educa- 
tion and health in particular, in addition to the consequent negative effects on the national economy [22] ${ }^{1}$. There are also indirect negative results, including the implications of the closure of shops, banks and disrupted public transport in many of the demonstrations sites. The direct negative effects of the demonstrations that turn into popular revolutions, particularly when violence is used by the regime, is symbolized by the loss of life of some protestors. There are some who are interested in estimating the value of life, including W. Kip Viscusi, who estimated the value of an American citizen's life by about US $\$ 7.5$ million in 2000, and of course, this value vary from one country to another and within the same country from time to time, but the fact that does not change is that the loss of life represents the biggest loss of demonstrations and revolutions, also the spread of chaos and lack of economic and political stability exerts a negative impact on the volume of executed investments and leads to a decline of future investment plans. Demonstrations may somehow prevent the flow of goods and services into the market, which means lower commodity supply on one hand and increasing the stock on the other and both lead to higher prices either due to lack of supply as in the first case or the increased costs of production due to increased storage costs, as in the second case.
Government's response to factional demonstrations, facing material losses and compensation for life casualties would lead to increase in government spending, this together with the inability of the productive body to respond with an increase in production, prices will rise and inflation spreads, which negatively affects the purchasing power. As well as the finance of government spending may be through pumping new money and increasing the money supply in the market which also boosts inflationary pressures. The sense of insecurity during demonstrations may drive citizens to buy more goods and services for storage, leading to higher prices. Demonstrations lead to widespread insecurity and then high element of risk, and thus higher values of insurance premiums borne by the seller who may convert the burden to the consumer by raising the price of the product, which means more inflationary pressures. To fund losses resulting from demonstrations, governments may have to raise taxes, cut government spending, issue new cash bills or resort to borrowing whether from home or abroad through the issuance of government bonds. Figure 2 shows government dependence on issuing new bonds to fund demonstrations losses and then bonds supply increases moving the supply curve of bonds from $S_{1 \text { bonds }}$ to $S_{2 \text { bonds }}$ and thus changing the balance point from A to B leading to lower

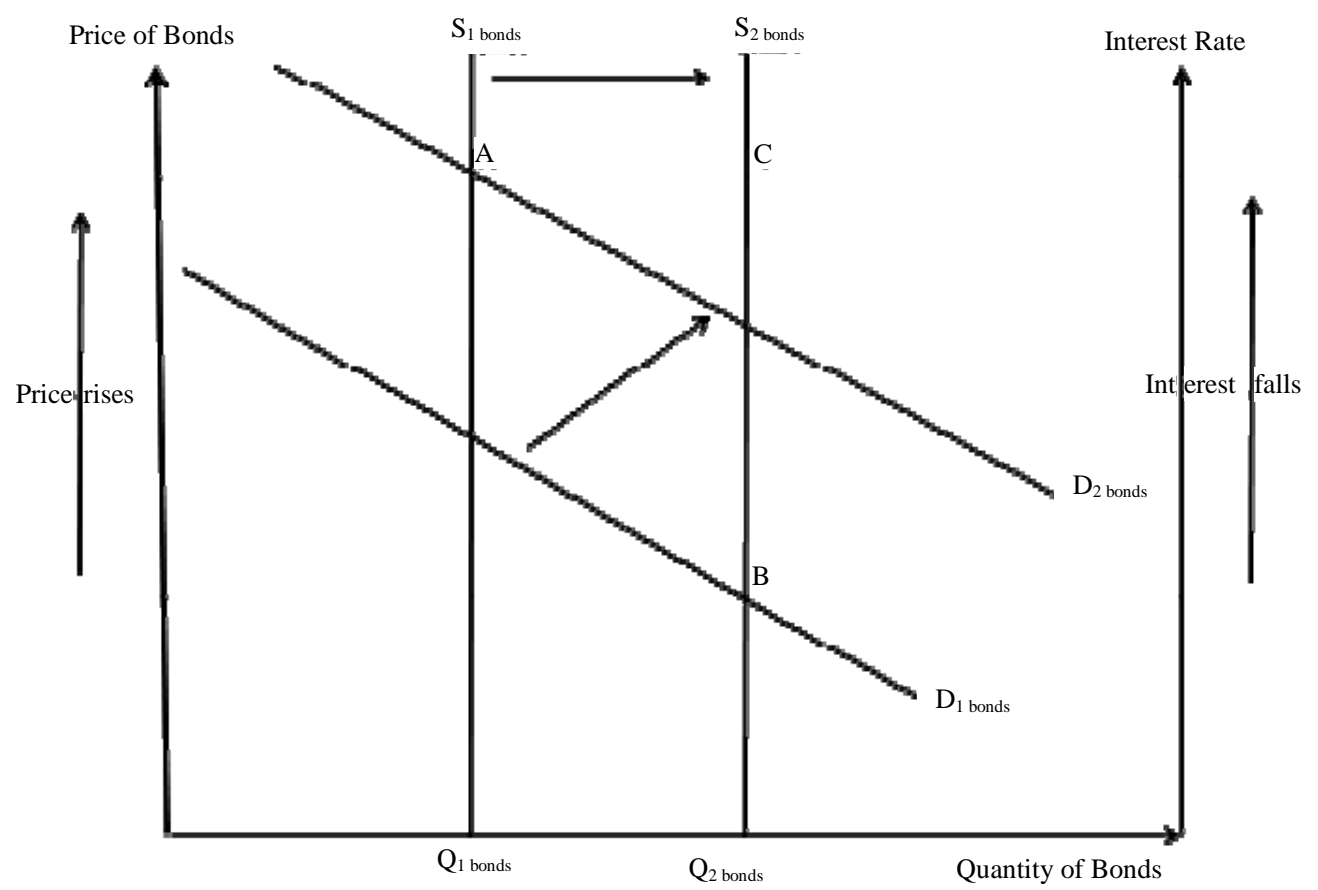

Figure 2. Ways of funding political unrest. Source: P. Poast, The economics of war, 2006.

\footnotetext{
${ }^{1}$ Some decide that war affects the national economy through two effects, the "Psychological Effect" on individuals, as the fear of individuals from political unrest lowers their spending desire, thus consumption and investment decrease and then the domestic product and income, but soon this effect disappears and individuals are back to their spending nature. The second effect is called the "Real Effect", where increased government spending on weaponry and various equipment leads to increased domestic product and income on the short-term, but leads to higher prices after that, the final impact of wars depends on several factors, including state of the economy before the war, war prevalence. And the diversion of resources from civilian to non-civilian production, and finally the duration of the war and its cost and financing methods.
} 
bond prices from $\mathrm{P}_{1}$ to $\mathrm{P}_{2}$ and consequently, the decrease in bond prices rises interest rates from $i_{1}$ to $i_{2}$. The government may see that they cannot afford to pay the high interest of bonds, thus, they might resort to issue new cash bills, buy the bonds that they have already issued, thus increasing the demand on these bonds which increase their prices and lower their interest and the new equilibrium is achieved at the point $\mathrm{C}$.

Interest rates are used as a tool in controlling inflation. However, they can also have an impact on consumer spending. Sometimes interest rates may have little impact; however, if they coincide with other factors, they can cause a much bigger than expected fall in consumer spending. Another issue is interest rates can have a delayed effect. e.g. the effect of interest rate increases last year may continue to affect consumer spending for up to 18 months.

Studies indicate that political unrest adversely affect the flow of products across countries as a result of insecurity on the one hand and as a result of delays in obtaining licenses and entry of products to importing countries on the other, for example, the trade between countries is reduced by $6 \%$ as a result of increased terrorist incidents in one country [23].

The deterioration of the total variables in the national economy is reflected negatively on the value of the local currency, which constitutes a burden on the national economy in many respects, the most important of them is the rising value of debt in foreign currencies and the high value of imports in foreign currencies, as well as the decline in domestic exports estimated in national currency.

Financial markets are affected by economic, political and financial stabilities prevailing in the national economy, also changes in the financial markets also exert influence on the national economy, their effect is mutual and they support each other.

\section{The Arab Spring Revolutions: Egyptian Revolution as a Model}

Following, we study the Egyptian revolution as a model for the Arab Spring revolutions, The selection of Egypt came because the aspects of political life were nearly complete, there is a Consultative (Shura) Council, a stable judiciary system and a stable government, there is also an elected assembly developing a new constitution in accordance with the demands of the people and revolution, as well as the presence of a President for the Republic elected by the people in free elections are characterized by a high degree of integrity and transparency.

\subsection{The Path of the Egyptian Revolution}

In protest over the poor living, political and economic conditions, as well as the political corruption that spread over the Egyptian economy, a number of Egyptian opposition groups and independent individuals, as well as groups of young people have decided using social networking sites to perform a number of popular movements on Tuesday, January 25, 2011 which was chosen to coincide with police day ${ }^{2}$.

The transformation of demonstration or protest movements into a popular revolution requires a variety of factors, including: First the demands of rebels must be legitimate and popular, that is there should be general consensus over them. Second, it should have organizational power to organize the pressure, escalation and negotiation processes to achieve the best results for the rebels and their demands. There is a critical factor in fueling the demonstrators and speed the turning of demonstrations into public revolution which is the fall of casualties among demonstrations due to violence against them by the regime, whether by the police, security forces, riot police or whatever name they had. Due to these factors demonstrations in Egypt have succeeded to turn into a popular revolution that destroyed the corrupt regime on February 11, and continued to achieve it goals despite the delay. The demands of the rebels were (bread-freedom-human dignity) which were popular demands supported by the Egyptian people of various sects and classes, as well as the positive leadership and organizational role played by the Muslim Brotherhood movement and other Islamic groups which helped a lot the success of the revolution, in addition that other parties and revolutionary forces joined force with the Islamists. Perhaps the most important event that turned demonstrations in Egypt into a popular revolution was the intervention of security to end violence at the dawn of January 26, then the use of excessive force with demonstrators on Friday 28 January, which was called the Friday of anger. In contrast, demonstrations in Bahrain failed in the transition to be a popular revolution, because they were not based legitimate demands of but religious demands backed only by one faction of the community, and not backed by the whole Bahraini people, as well as the wise behavior of the government in Bahrain and also moderate reckless actions by Security and police forces in dealing with the demonstrators, in addition to the fast response of the authorities to engage in dialogue with the leaders of the demonstrators have a significant impact on the containment of the demonstrations in the short term, and indeed, authorities had met a lot of the demonstrators' demands, but some demands were not answered because they lack legitimacy and consensus thus turning peaceful

\footnotetext{
${ }^{2}$ In manifestation of political corruption, elections for the parliament were conducted two months before the outbreak of the revolution and the ruling National Party won $97 \%$ of the seats meaning that the Council had devoid of any form of opposition, which struck the frustrated, citizens who described the elections as false especially that it does not reflect the reality on the Egyptian street.
} 
demonstrations into limited acts of sabotage in different parts of the country.

An example of incomplete political unrest and transition into a revolution is what happened on August 24, 2012, where 17 movement, coalition and political force called for demonstrate against President Mohamed Mursi and his party, those forces wanted to turn these events into a second revolution against the regime, but when the conditions for a Revolution were not available, the event remained at an isolated demonstration, despite all the media and political momentum given.

\subsection{Interpretation of the Length of the Transitional Period of the Egyptian Revolution}

Although the actual duration of the revolution on the regime in Egypt lasted from the twenty-fifth of January 2011 until the evening of 11th February 2011, the revolution was not completed until the election of the People's Assembly and the consultative Council, then the election of President of the Republic in the twenty-fourth of June 2012. In addition to the aforementioned factors the length of the period after the departure of former President until the election of President Mohamed Mursithe so-called transition period-can be attributed to several factors, including:

1) The presence of hope for some of the beneficiaries from the former regime to crush the revolution and return to the previous status, those people were called "the remainders or the counter-revolution". They have tried to terminate the revolution many times, but the awareness of the educated people in addition to increased political awareness of the public foiled those attempts, including the events of MASPERO, Mohamed Mahmoud and the syntax complex.

2) Blurred vision of many citizens and political forces which led to confused practices and acts. Once demonstrating in favor of the military council, and once against them, also once demonstrating in favor of the Muslim Brotherhood for their support to the revolution and once demonstrating against them for reasons that differ from time to time, accusing them Sometimes of exploiting and stealing the revolution, other times of concluding a deal whit the military council and again breaking their promises to the people.

3) Some external forces tried some political maneuvers in Egypt at times of political and security chaos.

4) The insistence of many sides to play a political role contrary to their role and responsibilities like the Supreme Constitutional Court, which had a big role in bringing many political problems in Egypt.

5) Weak political and economic performance by the military council during their administration of the coun- try whether intentionally or due to the lack of necessary experience $^{3}$.

\subsection{Merits of the Egyptian Revolution}

In addition to ending an era degradation and backwardness to the Egyptian state on all internal and external respects, the Egyptian revolution generated a new spirit that led the young generation not to think about migration abroad, and to contribute to the retrieval of the money stolen and smuggled abroad which is estimated at about $10 \%$ of GDP, the revolution also deepened the sense of pride and the sense of social responsibility that has grown in all segments of society, particularly honest businessmen. There is no doubt that this will have a significant impact on driving the growth and economic and social development in Egypt in the short and long term, also in the reduction of widespread corruption in the Egyptian society, and will provide a good structure for public, private and foreign investment.

\subsection{Interpretation of the Arab Spring Revolutions: The Need for a New Theory}

Analyzing the applicability of current theories that explain the political unrest on the Arab Spring revolutions and specifically on the Egyptian revolution, it is clear that the Arab Spring revolutions have special attributes, reasons as well as results. For example, in terms of the likelihood of political unrest in Egypt, estimates of the GDP per capita in Egypt indicate that, according to studies, the possibility of political unrest is less than $4 \%$. In terms of reasons for the outbreak of political unrest, the reasons behind the Arab Spring revolutions are different from the reasons of political unrest outbreak. The reasons in the case of the Arab Spring are accompanied by social and political reason at the same importance of economic reasons. the economic reasons in Egypt are manifested in the fact that about $40 \%$ of Egyptians live on \$2 per day, and then the mine challenge for Egypt is to create job for the unemployed on the one hand and achieve justice in the distribution of income and wealth on the other, where the unemployment rate reached $9 \%$ in 2010, and the unemployment rate among the graduates and postgraduate $20.1 \%$ in 2011. The poverty rate in Egypt has evolved from 17.2 to 24.3 then to 21.6 through the period of 1981/1982-2008, and GINI coefficient fluctuated through the same period (Table 1). In the year 2010, the average wage for a public sector worker was 542 and 299 pounds a week for a public and private sectors respectively [24]. Vertical inequality does not affect the presence or absence of political unrest, because measuring vertical equality does not tell anything about the rich and the

${ }^{3}$ The events of Maspero, Mohamed Mahmoud, the council of Ministers and the burning of the science complex are clear examples of this. 
Table 1. Some indicators of poverty in Egypt.

\begin{tabular}{ccc}
\hline Year & Poverty rate & GINI \\
\hline $1981 / 1982$ & 17.2 & NA \\
$1990 / 1991$ & 24.3 & 32.00 \\
$1995 / 1996$ & 19.4 & 30.13 \\
$1999 / 2000$ & 16.7 & NA \\
$2004 / 2005$ & 19.6 & NA \\
2008 & 21.6 & 36.1 \\
\hline
\end{tabular}

Source: Central Bank of Egypt, 2011.

poor, but horizontal inequality is the inequality distribution of income among different regions, ethnic groups and political and religious groups which represent a cause for political unrest especially if there was discrimination in favor of the groups represented in the power, the absence of equality in the distribution of income, especially horizontal equality, leads to dissatisfaction and the beginnings of the protest [25]. With respect to education in Egypt, enrollment rates in pre-primary education has reached $23 \%$ and $24 \%$ among female and male students for the year 2010/2011, in secondary education those rates reached $29 \%$ and $24 \%$ for female and male students respectively in the same year, the ratio between the number of students per teacher reached 27.1, 19.3 and 12.2 in the primary, preparatory and secondary stages respectively for the year 2010/2011 for public education, while in the private education, the percentages stands at 18.9, 12.3 and 13.1 in the primary, preparatory and secondary stages respectively, in the mentioned year, illiteracy rate among male reached $22.3 \%$ and females $37.3 \%$ in 2006 while the drop-out rate in primary education reached $2.37 \%$ in 2006 . The public spending on education represents $11.72 \%$ of the total public expenditure in the year 2010/2011 [26]. The social and political reasons are represented in the prevalence of corruption, nepotism and the lack of/delayed justice, inequality in rights and duties, low safety factor at home, weak sense of belonging and citizenship, sense of alienation at home, prevalence of the police state, sense of persecution, loss of rights and finally suppression of freedom ${ }^{4}$. Also the former regime was characterized by some of the Oligarchy system characteristics where a group of corrupt businessmen controlled various sectors of the economy

\footnotetext{
${ }^{4}$ Under the emergency law in place since 1967, except for a break for 18 months in the early eighties, police authority were expanded, constitutional rights suspended, censorship imposed and the non-government political activity was restricted. Also under the same law about seventeen thousand citizens were detained, and the number of political prisoners reached thirty thousand prisoners. Under this law, the Government has the right to detain any person for an indefinite period of time for a reason or for no apparent reason, people cannot defend themselves and the government can keep them in jail without trial.
}

and monopolized many of these sectors, and practiced all types of financial, economic and political corruption, such groups received all types of support from the former regime due to the convergence of interests, and where the presence and continuation of these corrupt groups means the continuation of the corrupt regime. Under that regime, the majority of citizens felt alienated in their home with less feeling of home and homeland.

On the other hand, the Arab spring revolutions differ from other political unrest on the side of the rebel groups formation .in the case of the Arab spring, the opposition (rebel) groups were formed over a long period of time, took many forms and were not moved by the first factor-looting seeking - but mostly evoked by the second factor-justice seeking — and also the rebel groups in the Arab spring were not armed. According to the prevailing economic theory in the economic literature, the feasibility factor is the most important for the continuation of the revolution, but this does not apply to the Arab spring revolutions, including the Egyptian revolution, where funding was not planned, and the revolution does not need financing because it was peaceful and does not need weapons nor equipment that requires financial resources $^{5}$.

The decisive factor in the continuation of the Arab Spring revolutions is the violence perpetrated by the regime against the demonstrators. The bloodshed and the fall of martyrs among the rebels acted like magic in fueling the courage, determination and perseverance in order to achieve the demands of the rebels on the one hand and also to avenge the martyrs on the other hand, this of course differs from other types of political unrest.

There is another difference for the Arab Spring revolutions, where communications through the Web and mobile phones played an important role in the events of the Egyptian revolution. The rebels had called and organized the beginning of the demonstrations on the twenty-fifth of January using social networking as well as text messages on mobile phones, they continued using those means during the revolution in coordinating and arrang-

\footnotetext{
${ }^{5}$ It is worth mentioning that opposition groups are not formed together at the same time, but with the passage of time and the continuation of the miserable conditions, those groups may have their differences especially in the specific goals, but they mostly agree on the main objectives which involve the need to change the reality to what is best for them. Finally, the formation of a group after another encourages others to venture and take the decision, and the credit will be largely attributed to the group that was formed first as they play a major role in breaking the fear factor, especially in communities where repressive actions against individuals are more. In Egypt, the KIFAYA (ENOUGH) movement was formed at the very beginning, which announced its rejection to the continuation of Mubarak in power raising their slogan KIFAYA, also rejecting the idea of inheriting the presidency by his son The movement has demonstrated on many occasions, and it can be said that they have great credit in encouraging many citizens to follow their ideas either by forming a coalition or an association, or even go out to the street to express their views.
} 
ing demonstrations and even to identify and unify the demands of the rebels, as well as the exchange of expertise and advice with others inside and outside Egypt ${ }^{6}$.

As for the costs of the transition period, these are characterized as being high public costs paid by all individuals alike as a result of their faith in their revolution and the need to pay the price for the change, growth and Renaissance, in the sense that there is neither a winner nor a loser in this revolution. Also those costs, in part, indicate how fragile were the economic and social systems formed during the era of the former regime, as evidenced by the large disparity between the levels of cash wages and their real levels, which led to huge number of factional protests for various sectors of the economy during the transition period, of which, some is still ongoing till now.

In sum, the Arab Spring revolutions have special features that distinguish them from all other conflicts, and therefore it needs special theory to explain these revolutions and set certain conditions for the eruption and conditions for continuing to reap stage.

\section{Concluding Remarks}

This study had tackled the concepts related to the Arab Spring and its economic causes, as well as its consequences, and the possibility to be interpreted in the light of the economic framework adopted in prevailing economic literature. The study adopted Egypt as a case study as the state where the Arab Spring had crystallized and achieved a considerable part of its soughed results. The study confirmed that the theories that explained the outbreak of conflicts in various forms had focused on the economic reasons, particularly the prevalence of poverty, inequality in income distribution and low levels of education, but it was a different case in the Arab Spring revolutions, where the social and political reasons play the most important role in the outbreak of these revolutions. Also, the Arab Spring revolutions have been formed and crystallized over time and it can be said that there were rehearsals for the Egyptian Revolution before the twenty-fifth of January on a number of occasions, but for the aforementioned reasons, those popular movements have turned into a revolution that swept across the country. The violence against the rebels and the fall of Martyrs were decisive factors in the continuation of the Arab Spring revolutions. Finally the use of communication technology and social networking represent an important dimension that adds an urgent need to provide a new theory for the outbreak of political unrest and its ability to continue and even achieve goals with escalating demands when the period of such unrest is extended. In a

${ }^{6}$ For example: A Tunisian citizen presented an advice across social networking for the Egyptian demonstrators on how to quickly deal with tear gas used by the Egyptian police to confront the rebels. more precise meaning, the economic literature needs a theory based on interpreting the active role of technology in the field of communication and social networking on the Arab Spring revolutions on the one hand, and show to what extent the impact of violence and fall of the martyrs and legitimate demands of rebels have on the continuation of the revolution and rebels on the other hand.

\section{Acknowledgements}

The author would like to thank Dr. Abdel Nasser Fatah Allah, College of Arts, Bahrain University, for his valuable discussions and comments in the earlier version of the paper. Also the author is grateful to anonymous referees.

\section{REFERENCES}

[1] Financial Times Limited, “The Banker,” 2012.

[2] T. Sandler, "Economic Analysis of Conflict," Journal of Conflict Resolution, Vol. 44, No. 6, 2000, pp. 723-729. doi:10.1177/0022002700044006001

[3] M. C. McGuire and M. Olson, "The Economics of Autocracy and Majority Rule,” Journal of Economic Literature, Vol. 34, 1996, pp. 72-96.

[4] M. Olson, "Power and Prosperity: Outgrowing Communist and Capitalist Dictatorships," Basic Books, New York, 2000.

[5] P. Lujala, N. P. Gleditsch and E. Gilmore, "A Diamond Curse? Civil War and a Lootable Resource,” Journal of Conflict Resolution, Vol. 49, No. 4, 2005, pp. 538-556. doi:10.1177/0022002705277548

[6] P. Collier and A. Hoeffler, "Military Expenditure in PostConflict Societies," Economics of Governance, Vol. 7, No. 1, 2006, pp. 89-107. doi:10.1007/s10101-004-0091-9

[7] H. I. Grossman, "Insurrections,” In: K. Hartley and T. Sandler, Eds., Handbook of Defense Economics, Vol. 1, Elsevier Science B. V., Amsterdam, 1995.

[8] J. P. Azam, "How to Pay for the Peace? A Theoretical Framework with Reference to African Countries," Public Choice, Vol. 83, No. 1-2, 1995, pp. 173-184. doi:10.1007/BF01047691

[9] P. Collier, "On the Economic Consequences of Civil War,” Oxford Economic Papers, Vol. 51, No. 1, 1999, pp. 168-183. doi:10.1093/oep/51.1.168

[10] P. Collier and A. Hoeffler, "Greed and Grievance in Civil War,” World Bank, Policy Research Working Paper 2355, 2000.

[11] T. Ellingsen, “Colorful Community or Ethnic Witches' Brew? Multiethnicity and Domestic Conflict during and after the Cold War,” Journal of Conflict Resolution, Vol. 44, No. 2, 2000, pp. 228-249. doi:10.1177/0022002700044002004

[12] P. Collier and A. Hoeffler, "On the Economic Causes of Civil War,” Oxford Economic Papers, Vol. 50, No. 4, 1998, pp. 563-573. doi:10.1093/oep/50.4.563 
[13] P. Collier and A. Hoeffler, "Greed and Grievance in Civil War,” Oxford Economic Papers, Vol. 56, No. 4, 2004, pp. 563-596. doi:10.1093/oep/gpf064

[14] B. A. Most and H. Starr, "Inquiry, Logic, and International Politics,” University of South Carolina Press, Columbia, 1989.

[15] P. Collier, A. Hoeffler and M. Söderbom, "On the Duration of Civil War," Journal of Peace Research, Vol. 41, No. 3, 2004, pp. 253-273. doi:10.1177/0022343304043769

[16] P. Collier, "Doing Well out of War in Greed and Grievance: Economic Agendas in Civil Wars,” Lynne Rienner, Boulder, 2000.

[17] T. Addison, P. Le Billon and S. M. Murshed, "Finance in Conflict and Reconstruction," World Institute for Development Economics Research (WISER) DP 2001/44, UN University, 2001.

[18] P. Collier and A. Hoeffler, "On the Incidence of Civil War in Africa,” Journal of Conflict Resolution, Vol. 46, No. 1, 2002, pp. 13-28. doi:10.1177/0022002702046001002

[19] M. Humphreys, "Economics and Violent Conflict," Harvard University, Boston, 2003. www.preventconflict.org/portal/economics

[20] J. Hirshleifer, "The Technology of Conflict as an Economic Activity," American Economic Review: Papers and Proceedings, Vol. 81, 1991, pp. 130-134.

[21] J. Hirshleifer, "The Dark Side of Force: Economic Foundations of Conflict Theory,” Cambridge University Press, Cambridge, 2001.

[22] S. Gupta, B. Clements and R. Bhattacharya, "Fiscal Dimensions of Armed Conflict," The Economic Consequences of Global Terrorism Workshop, Deutsches Institut fur Wirtschaftsforschung, Burlin, 2002.

[23] V. Nitsch and D. Schumacher, "Terrorism and Trade, Paper for Workshop. The Economic Consequences of Global Terrorism,” DIW/German Institute for Economic Research, Berlin, 2002.

[24] Central Bank of Egypt, “The Annual Report, Statistical and Economic Report Section,” Egypt, 2011.

[25] P. Poast, “The Economics of War," McGraw-Hill, New York, 2006.

[26] Central Agency for Public Mobilization \& Statistics (CAPMAS), "Statistical Book,” 2011. 